\title{
Analysis Science Literacy Competency of High School Student Through Chemistry Learning Based on Projects Integrated Ethnoscience
}

\author{
Ariyatun $^{1}$, Sudarmin $^{2}$, Sulistyaningsih Triastuti ${ }^{3}$ \\ \{ariyatun2017@students.unnes.ac.id ${ }^{1}$; sudarmin@mail.unnes.ac.id²; triastuti.s@mail.unnes.ac.id ${ }^{3}$ \} \\ Department of Postgraduate Chemistry Education, Universitas Negeri Semarang, Indonesia ${ }^{1,2,3}$
}

\begin{abstract}
This research aims to analyze the immersion of scientific literacy competencies of students through chemistry learning based on project integrated ethnoscience. This research used descriptive quantitative methods. Students of class XI MIPA SMAN 1 Kendal were selected as sample using purposive sampling technique. The research instrument used was a multiple-choice chemical literacy test with reasons from the aspects of scientific literacy competence in colloid chemistry. There were three indicators on the competency aspects of scientific literacy studied, those were explaining scientific phenomena, evaluating and designing scientific investigations and interpreting scientific data and evidence with the results of the percentage of each indicator amounting to $82.43 \% ; 86.08 \%$; and $67.63 \%$. The results of the average achievement of scientific literacy competency in colloidal material as a whole were $78.15 \%$ in the good category. The conclusion of this research projects chemistry learning integrated ethnoscience was able to develop students' scientific literacy competency.
\end{abstract}

Keyword: science literacy, project based learning, ethnoscience

\section{Introduction}

Scientific literacy skills in understanding scientific issues, risks and benefits of science, as well as understanding the nature of science, including its relationship with culture were very important for every individual to master because the development of science and technology was increasingly rapid [1-2]. In the development of science and technology today, scientific literacy skills can be used by modern society to understand the environment, apply scientific concepts, and use scientific process to solve problems and make decisions in daily life based on scientific evidence [3-4]. Understanding chemical explanations and educating people to be chemical literacy was very important because our environment was strongly influenced by chemicals and it was mostly filled with chemicals. So the chemical explanation has a practical application in everyday of life [5].

Efforts to improve science learning in the schools need to be carried out step by step, continuous and directed manner and improve the quality of learning in schools needs to be supported by information on students' scientific literacy achievements in terms of their aspects and adapted to national education goals [6]. In this era, Science education that took into account local culture, wisdom, national identity, character and local cultural habits was one thing that needs to be considered in the development of the curriculum 2013 [7]. The paradigm for science education was currently based on local culture and wisdom as an effort to improve students' 
scientific literacy [8]. The importance of cultural integration in science learning (ethnoscience) was delivered by Nieto \& Booth that integrating cultural competencies will be a determinant of professional meaning in education services, so that teachers must be able to raise cultural elements to be accommodated in learning [9]. In addition, learning was also needed to provide opportunities for students to determine their own learning process, conduct education and encourage students to demonstrate their understanding in the form of creative projects [10].

Project based learning is one of the scientific learning models that has been widely researched and it was thought to be effective in improving scientific literacy [11] and attitudes towards science [12]. This study referred to the PISA assessment which one of the domains of scientific literacy assessed was the aspect of competence, those were three key competencies in 2015 PISA scientific literacy described in the 2015 Draft Science Framework Framework [13] output documents, including: 1) Explain scientific phenomena; 2) Evaluating and designing scientific investigations; and 3) Interpreting scientific data and evidence [14]. The PISA literacy test aimed to describe the extent which students can apply their knowledge in relevant contexts in daily lives. The purpose of this study was to analyze the scientific literacy competency skills of high school students. The results of the study were expected to provide information about the profile achievement of chemical literacy competencies through learning chemistry-based integrated ethnoscience projects so that they can be used as references as an effort to improve students' chemical literacy competencies in the future.

\section{Methods}

\subsection{Sample characteristics and sampling method}

The population of this study was all of eleventh grade MIPA students in SMAN 1 Kendal. The sample of this study was XI MIPA 3 class that obtained by purposive sampling with a total of 34 students.

\subsection{Research Design}

The research method used in this study was a quantitative descriptive research.

\subsection{Data collection}

The research instrument used in this study was a multiple choice chemical literacy test. The research instrument was validated and then carried out by testing the problem.

\subsection{Analysis}

Based on the results of statistical analysis with the help of the "Iteman" application showed that Alpha prices were 0.687 so that the reliability coefficient of the test made was 0.687 belongs to medium category. The calculation results showed the average difference in power of the questions in the test was 0.283 (rpbi) or 0.409 (rbis) with the classification of questions acceptable [15]. The results of the research data were analyzed by calculating the percentage of achievement of scientific literacy assisted by the Microsoft Office Excel program, the percentage of achievement of scientific literacy then interpreted descriptive quantitative. 


\section{Results and Discussion}

The result of research data was related to scientific literacy skills in each indicator of scientific literacy competency that obtained by calculating the percentage of achievement of test results for each indicator then comparing the scores obtained by each student with maximum scores and looking for an average value of achievement in scientific literacy competency for each-one indicator. Then, the overall percentage of each scientific literacy competency indicator was analyzed for each indicator presented in Table 1.

Table 1. Result of Science Literacy Competency Test

\begin{tabular}{lcc}
\hline The Indicator of Science Literacy Competency & Percentage (\%) & Criteria \\
\hline Explaining Scientific Phenomena & 82.43 & Very Good \\
Evaluating and Designing Scientific Investigation & 86.08 & Very Good \\
Interpreting Scientific data and the Evidence & 67.63 & Good \\
\hline
\end{tabular}

Achieving competencies for each indicator showed that in scientific phenomena indicator achieved $82.43 \%$. It belongs to very good category that was shown by the students' ability in applying the scientific knowledge. They have acquired in solving scientific literacy problems to the concept of colloidal. The concept of student's knowledge affected the other students in describing the scientific phenomena they encountered. In the project-based chemistry learning integrated ethnoscience of chemistry learning that was taught cannot be separated from the social context and focus on mastering the material in preparing knowledge that must be known. The cultural background possessed by students and brought into class during the learning process has very important role in the process of mastering the subject matter. The cultural background of students has a greater effect in the education process than the effects provision of subject matter. The cultural background of each student influenced the way students learn and master the scientific concepts taught in school [16].

The achievement of scientific literacy competencies in evaluating and designing scientific investigations indicator achieved $86.08 \%$. It was illustrated by students' ability in identifying questions which were explored through scientific inquiry, distinguishing questions that can be scientifically investigated, also explaining and providing scientifically experimental hypotheses on test instruments scientific literacy competency. The ability of students was closely related to the knowledge they have understood regarding the concept of colloidal based on the projects they were working on their worksheets integrated with ethnoscience. The analysis questions on literacy items related to the student's cognitive aspects of the phenomena that was commonly encountered in their lives. Based on cognitive learning theory, students used their initial knowledge to process new information by connecting the new information with their initial knowledge [17].

The indicator of interpreting data and evidence got the lowest percentage among other indicators which was equal to $67.63 \%$ in the good category. It was because the students did not fully understand how to interpret and prove experimental data scientifically so that it influenced the process of analyzing and interpreting data and attracting conclusions appropriately. The achievement of these three competencies was a requirement that must be met by someone who was knowledgeable. The first competency was to explain phenomena scientifically, demanding knowledge of the contents of science or what was known as content knowledge. The second and third competence was required more than knowledge of what we know. In contrast, the first and 
third competencies depended on the understanding of how scientific knowledge was built and the level of trust that existed [13].

By the chemistry learning based on the integrated ethnoscience project, students can find out the relevance of chemical science learning to daily life and community life and also directed in understanding how important chemistry when it was associated with society in the past, now or future [18]. Learning chemistry needs to be pursued, so that there was a balance between the knowledge of chemistry itself, the cultivation of scientific attitudes, and the value of local competitiveness that developed in society. The socio-cultural environment needed to get serious attention in developing chemical science education because it contained a real of science that can be useful for life in society [10].

Someone who has scientific literacy was able to use an understanding of science in their life [19]. Science literacy as a broad concept, in mastering chemistry will affect the quality of someone's life. Individual achievements in science / chemistry knowledge and skills will have implication for their readiness to face the technology era in the future [14]. In addition, learning model and approach was one of the factors that influenced the results of this scientific literacy study as the aspect of scientific attitudes relating to emotional factors that include interest and comfort in science learning and student involvement in learning science [20]. So, aspects of knowledge, competence, and attitudes affected the achievement of science literacy skills of high school student. Reconstruction of the science in this study conducted by brick makers in Kendal to express genuine knowledge (indegeneius science) of making bricks. Of respondents obtained information related to the original science of processing these bricks. Then discover the original science knowledge society transformed into scientific science, and the results are presented in Table 2.

Table 2. The Reconstruction Results of Indigenous Knowledge into Scientific Knowledge

\begin{tabular}{|c|c|c|}
\hline Focus Questions & Indigenous Knowledge & Scientific Knowledge \\
\hline Understanding Clay & $\begin{array}{l}\text { Clay is weak clay is } \\
\text { smooth. }\end{array}$ & $\begin{array}{l}\text { Clay or clay is a mineral particle with a silicate } \\
\text { base frame less than } 4 \text { micrometers in diameter, } \\
\text { containing fine fused silica and aluminum. Clay } \\
\text { is formed from the process of weathering silica } \\
\text { rocks by acids and some is produced from } \\
\text { geothermal activity. Soil contains kaolinite } \\
\left(\mathrm{AL}_{2} \mathrm{Si}_{2} \mathrm{O}_{5}\right) \text { which is formed from hydrothermal } \\
\text { alteration of alumino silicate minerals [21]. }\end{array}$ \\
\hline $\begin{array}{ll}\text { The function of } \\
\text { adding bran or } \\
\text { sawdust }\end{array}$ & $\begin{array}{l}\text { Bran or sawdust is used to } \\
\text { glue the bricks. }\end{array}$ & $\begin{array}{l}\text { The addition of sawdust in the manufacture of } \\
\text { bricks serves to influence the mechanical } \\
\text { properties of bricks by reducing the porosity and } \\
\text { shrinkage of fuel and increasing the strength of } \\
\text { bricks. The addition of bran by } 5 \% \text { can optimize } \\
\text { the compressive strength of bricks. Balanced } \\
\text { addition can maximize the function of } \mathrm{Al}_{2} \mathrm{O}_{3} \text { in } \\
\text { clay as an adhesive [22]. }\end{array}$ \\
\hline
\end{tabular}




\begin{tabular}{|c|c|}
\hline Focus Questions & Indigenous Knowledge \\
\hline 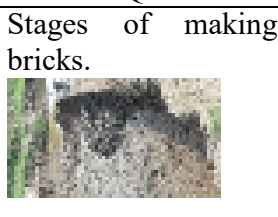 & $\begin{array}{l}\text { Extracting raw materials: } \\
\text { land is taken from river } \\
\text { banks, people call it weak } \\
\text { latri. This land contains a } \\
\text { mixture of arena sand from } \\
\text { the flowing river. }\end{array}$ \\
\hline
\end{tabular}

The process of Processing raw materials: erasing clay dough, bran or sawdust.

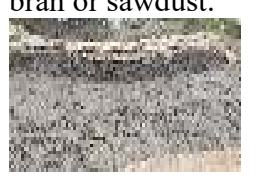

Brick printing

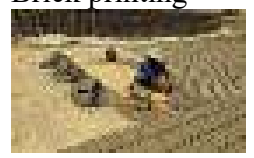

Drying bricks

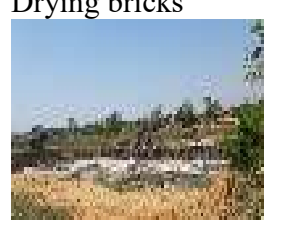
clay mixed with river water, bran or grejen wood, then dieramkan for 1 night prior to printing.

Scientific Knowledge

The excavation of raw bricks should be found not too plastic soil, but rather soil containing a little sand to avoid shrinkage. Excavation is carried out on topsoil about $40-50 \mathrm{~cm}$ thick. The excavated land is collected and stored in a protected place. The longer the clay is stored, the better it will become weathered. This stage is intended to decompose organisms that exist in clay [23].

Clay must be mixed evenly before making red brick called dozing by adding a little water. The mixture added during processing must be completely fused with clay evenly. The raw material that has been made before being formed by molding, is first left for 2 to 3 days with the aim of giving clay particles an opportunity to absorb water so that it becomes more stable, so that when formed there will be an even shrinkage [24].

The first step in brick molding is to place the mold on the printing ground floor, then the ready clay is placed on the molding frame by hand while being pressed until the clay meets all the corners of the room on the molding frame. Furthermore, the mold is lifted and the raw brick resulting from the mold is left alone so that it is exposed to sunlight. The raw bricks are then collected in a protected place to be aerated [25]

The drying process: dried under direct sunlight for a few days, with the bottom covered with plastic.
The process of drying bricks will be better if it takes place gradually so that heat from the sun does not fall directly, it is necessary to install a plastic cover. If the drying process is too fast in the sense that the sun's heat is too strong it will cause cracks in the bricks later. The drying process of bricks takes two - seven days depending on the weather. 


\begin{tabular}{|c|c|c|}
\hline Focus Questions & Indigenous Knowledge & Scientific Knowledge \\
\hline 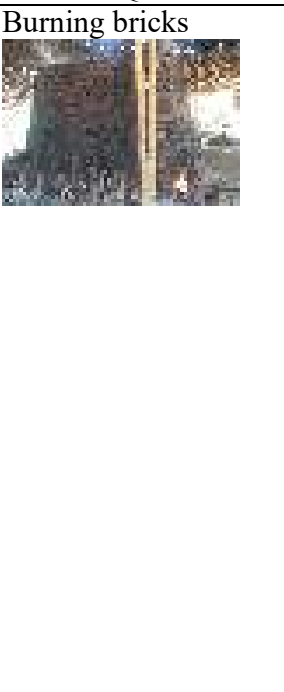 & $\begin{array}{l}\text { Burning of bricks: bricks } \\
\text { laid by providing gaps } \\
\text { between the bricks and add } \\
\text { ashes in the middle order of } \\
\text { bricks that do not quickly } \\
\text { extinguished the fire. }\end{array}$ & $\begin{array}{l}\text { The process of burning bricks must be balanced } \\
\text { with the increase in temperature and temperature } \\
\text { speed, there are several stages that must be } \\
\text { considered, namely: [26] } \\
\text { Stage 1: evaporation (drying), i.e. forming } \\
\text { water. } \\
\text { Stage 2: oxidation, combustion of plant debris } \\
\text { (carbon) found in the clay. This process takes } \\
\text { place at a temperature of } 650^{\circ} \mathrm{C}-800^{\circ} \mathrm{C} \text {. } \\
\text { Stage 3: full combustion. The bricks are burned } \\
\text { until cooked and the sintering process takes } \\
\text { place to become solid bricks. Mature } \\
\text { temperatures vary between } 920^{\circ} \mathrm{C}-1020^{\circ} \mathrm{C} \\
\text { depending on the nature of the clay used. } \\
\text { Stage } 4 \text { : containment. At this stage detentions } \\
\text { temperature for } 1-2 \text { hours.In stage } 1,2 \text { and } 3 \\
\text { should temperature rise slowly, to avoid losses } \\
\text { on the bricks. Among others: cracked, black } \\
\text { stains on the brick, development, and others. }\end{array}$ \\
\hline $\begin{array}{l}\text { Extra functions rice } \\
\text { husk ash }\end{array}$ & $\begin{array}{l}\text { Abu serves to glue the soil } \\
\text { and the results can be more } \\
\text { dense. }\end{array}$ & $\begin{array}{l}\text { Combustion ash containing active silica-alumina } \\
\text { compounds that can react with calcium } \\
\text { hydroxide at room temperature and the presence } \\
\text { of water at certain levels can form stable } \\
\text { compounds that have binding properties. }\end{array}$ \\
\hline
\end{tabular}

\section{Conclusion}

Through chemistry-based learning projects integrated with ethnoscience, scientific literacy skills of students in the three indicators of scientific literacy competency explaining scientific phenomena (82.43\%), evaluating and designing scientific investigations (86.08\%) and interpreting scientific data and evidence $(67.63 \%)$ can develop well. Chemistry learning based on projects integrated ethnoscience can be used as a point of view in providing the best treatment to students and it was expected that with the application of chemical learning integrated ethnoscience the ability of chemical literacy competencies and attitudes towards science can develop well. Chemistry learning based on projects integrated ethnoscience is able to strike a balance between the knowledge of chemistry itself, the inculcation of scientific attitudes, and the value of local skills that develop in the community. 


\section{References}

[1] McCright, A. M.: Enhancing Students' Scientific and Quantitative Literacies through an InquiryBased Learning Project on Climate Change. Journal of the Scholarship of Teaching and Learning, 12(4), pp. 86-101 (2012).

[2] Fasasi, R. A.: Effects of Ethnoscience Instruction , School Location , and Parental Educational Status on Learners Attitude Towards Science, (March) pp. 1-17 (2017).

[3] Turiman P., Omar J., Daud A M., \& O. K.:Fostering the 21st Century Skills through Scientific Literacy and Science Process Skills. Procedia - Social and Behavioral Sciences. 59, pp. 110-116 (2012)

[4] Lutfi. R., Suwono.H \& Susilo, H..: Analisis Kemampuan Awal Literasi Sains Siswa SMA Kota Malang. Prosiding Seminar Nasional II Universitas Muhammadiyah Malang. pp. 771-781 (2016).

[5] Gilbert, J. K., \& Treagust, D.: Multiple Representations in Chemical Education vol 4. Dordrecht: Springer (2009).

[6] Asyhari, A. : Profil Peningkatan Kemampuan Literasi Sains Siswa Melalui Pembelajaran Saintifik. Jurnal Ilmiah Pendidikan Fisika Al-Biruni, 4(2), pp. 179 (2015)

[7] Sudarmin, S., Mursiti, S., \& Asih, A. G.: The Use Of Scientific Direct Instruction Model With Video Learning Of Ethnoscience To Improve Students' Critical Thinking Skills. In Journal of Physics: Conference Series (Vol. 1006, No. 1, p. 012011). IOP Publishing (2018).

[8] Fibonacci, A., \& Sudarmin, S.: Development Fun-Chem Learning Materials Integrated SocioScience Issues to Increase Students Scientific Literacy. International Journal of Science and Research (IJSR), 3(11), pp. 708-713 (2014).

[9] Nieto, C., \& Booth, M.: Cultural Competence: Its Influence on the Theaching and Learning of International Education. Jurnal of Studies in International Education, 14 (4), pp. 406-425 (2010).

[10] Nisa, A., Sudarmin, S.: Efektivitas Penggunaan Modul Terintegrasi Etnosains dalam Pembelajaran Berbasis Masalah untuk Meningkatkan Literasi Sains Siswa. Unnes Science Education Journal, 4(3), pp. 1049-1056 (2015).

[11] Afriana, J., Permanasari, A., \& Fitriani, A.: Project Based Learning Integrated To Stem To Enhance Elementary School's Students Scientific Literacy. Jurnal Pendidikan IPA Indonesia, 5(2), pp. 261-267 (2016).

[12] Tseng, K. H., Chang, C. C., Lou, S. J., \& Chen, W. P.: Attitudes Towards Science, Technology, Engineering And Mathematics (STEM) In A Project-Based Learning (PjBL) Environment. International Journal of Technology and Design Education, 23(1), pp. 87-102 (2013).

[13] Organisation for Economic Co-operation and Development: PISA 2015 Draft Collaborative Problem Solving Framework. OECD Publishing (2013).

[14] Organisation for Economic Co-operation and Development: PISA 2012 Assessment And Analytical Framework: Mathematics, Reading, Science, Problem Solving and Financial Literacy. OECD Publishing (2013).

[15] Rusilowati, A.: Pengembangan Instrumen Penilaian (cet-1). Semarang:UNNES PRESS (2014).

[16] Sumarni, W.: Pembelajaran Kimia Dalam Kehidupan Berbasis Proyek Terintegrasi Etnosains Bagi Mahasiswa Calon Guru. Disertasi. Universitas Negeri Semarang (2018).

[17] Wulandari.N \& Sholihin: Analisis Kemampuan Literasi Sains Pada Aspek Pengetahuan Dan Kompetensi Sains Siswa SMP Pada Materi Kalor. Edusains, 8(1), pp. 66-73 (2016).

[18] Shidiq, A. S.: Pembelajaran Sains Kimia Berbasis Etnosains Untuk Meningkatkan Minat Dan Prestasi Belajar Siswa. Seminar Nasional Kimia Dan Pendidikan Kimia (SNKPK) VIII, pp. 227 236 (2016).

[19] Wei, B., \& Thomas, G.: Rationale and Approaches for Ebbedding Scientific Literacy into the New Junior Secondary School Chemistry Curriculum in the Peoples Republic of China. International Journal of Science Education, 27(12), pp. 1477-1493 (2010).

[20] Huann, S. L., Zuway, R. H., Tai, C., H.: The Role of Emotional Factors in Building Public Scientific Literacy and Engagement with Science. International Journal of Science Education 34 (1), pp. 25-42 (2012).

[22] Handayani, S. (2010). Kualitas Batu Bata Merah Dengan Penambahan Serbuk Gergaji. Jurnal 
Teknik Sipil dan Perencanaan, 12(1), 41-50.

[22] Handayani, S. Kualitas Batu Bata Merah Dengan Penambahan Serbuk Gergaji. Jurnal Teknik Sipil dan Perencanaan, 12(1), 41-50. (2010).

[23[ Indra, A. Kuat Tekan (Compression Strength) Komposit Lempung/Pasir pada Aplikasi Bata Merah Daerah Payakumbuh Sumbar. Jurnal Teknik Mesin (JTM), 2(1). (2013).

[24] Handayani, S. Kualitas Batu Bata Merah Dengan Penambahan Serbuk Gergaji. Jurnal Teknik Sipil dan Perencanaan, 12(1), 41-50. (2010).

[25] Handayani, S. Kualitas Batu Bata Merah Dengan Penambahan Serbuk Gergaji. Jurnal Teknik Sipil dan Perencanaan, 12(1), 41-50. (2010).

[26] Suwardono. Mengenal Pembuatan Bata,Genteng,Genteng Berglasir, Cetakan Ketiga. Bandung: CV. Yrama Widya. (2010). 